Countertransference issues in psychotherapy with lesbian and gay clients

Martin Milton, Adrian Coyle and Charles Legg

University of Surrey and City University

Correspondence to: Dr Martin Milton, Department of Psychology, University of Surrey, Guildford, Surrey GU2 7XH, UK. Tel. 01483 689176. Email:

M.Milton@surrey.ac.uk

The full reference for the published version of this article is:

Milton, M., Coyle, A., \& Legg, C. (2005). Countertransference issues in psychotherapy with lesbian and gay clients. European Journal of Psychotherapy, Counselling and Health, 7, 181-197. 
Martin Milton is a Chartered Counselling Psychologist and Registered Psychotherapist. He is a Senior Lecturer with the Practitioner Doctorate in Psychotherapeutic and Counselling Psychology in the Department of Psychology at the University of Surrey.

Adrian Coyle is a Senior Lecturer and Course Director for the MSc Programme in Social Psychology in the Department of Psychology at the University of Surrey.

Charles Legg is a Chartered Counselling Psychologist and Senior Lecturer in the Department of Psychology at City University, London. 


\title{
Countertransference issues in psychotherapy with lesbian and gay
}

\section{clients}

\begin{abstract}
This article briefly reviews literature on responses towards same-sex (lesbian and gay) sexualities from psychoanalytic and 'lesbian and gay affirmative’ psychotherapeutic perspectives. An analysis is presented of reports of countertransferential reactions to lesbian and gay clients, obtained from interviews with 14 psychotherapists who work in a lesbian and gay affirmative manner and 18 clients who had received affirmative psychotherapy. Data were subjected to grounded analysis. Participants consistently attended to the thoughts, feelings and values that therapists held in relation to lesbian and gay clients and how these affected the meanings and practices available to them. These were linked with the therapist's sexual identity among other factors. Negative countertransferential reactions were regarded as potentially occurring among heterosexual and lesbian and gay therapists and were seen as arising from therapists' conscious and unconscious fears about same-sex sexualities. These findings indicate a need to continue debating these issues more widely in the professional arena.
\end{abstract}

Keywords: affirmative therapy; countertransference; lesbian and gay 


\section{Countertransference issues in psychotherapy with lesbian and gay}

\section{clients}

\section{Introduction}

Contemporary literature within many psychotherapeutic approaches shows evidence of reconsidering the relationship between psychotherapeutic theory and same-sex (lesbian and gay) sexualities. This can be seen across a range of models including the psychoanalytic/psychodynamic (O’Connor and Ryan, 1993; Cornett, 1995; Domenici and Lesser, 1995; Ratigan, 1998; Dreschner, 1999; Izzard, 1999, 2000), humanistic (Davies, 2000; Perlman, 2000; Silvester, 2000), cognitive-behavioural (Ussher, 1990), systemic (Laird and Green, 1996; Malley and Tasker, 1999; Malley and McCann, 2002) and existential-phenomenological (Spinelli, 1996, 1997; Cohn, 1997; du Plock, 1997; Milton, 2000). Within the literature, the therapist's own stance towards samesex sexualities is frequently addressed. As with so many elements in psychotherapy, the perspectives of other schools can be seen at least in part as an elaboration of, a reaction to or simply related to psychoanalytic perspectives. It is therefore useful to consider how psychoanalytic literature relates to the wider literature on psychotherapeutic stances towards same-sex sexualities. This paper briefly reviews the literature on this issue and presents findings from a qualitative study relevant to psychotherapists' countertransferential responses to lesbian and gay clients.

Countertransference is a central concept within psychoanalytic literature, although definitions of this concept have varied in their specificity. Smith (1991) observed that 'Freud equated countertransference with the way analysts' blind spots, complexes and inner resistance hamper their effective psychoanalytic functioning' (p.47). Thus, 
countertransference can be seen as an aspect of the therapist that can potentially limit their therapeutic endeavours (although if properly acknowledged and processed, it can of course also constitute a valuable therapeutic resource). Some psychoanalytic insiders have argued that psychoanalysis's traditional lack of attention to its countertransferential response to same-sex sexualities limits any possible benefit that may accrue to clients or therapists and therefore requires urgent attention (Kwawer, 1980; Lewes, 1995; Ryan, 1998). This viewpoint finds support when we review the stances that psychoanalysis has taken to same-sex sexualities throughout the course of its history.

\section{Psychoanalytic Perspectives on Same-Sex Sexualities: An Overview}

Freud's contribution to debates about homosexuality can be seen in various ways. Spencer (1995) has argued that Freud's contribution, whilst influential, was 'highly equivocal' (p.319); indeed, he contended that Freud's perspective may have been crucial to the development of a climate in which the professional pathologisation of same-sex sexualities became possible and legitimate. However, the opposite has also been suggested - that by considering human sexuality as 'polymorphously perverse', Freud problematised sexuality in general rather than one particular form of sexuality. It has been claimed that this made it legitimate to consider diverse forms of sexuality, together with their potential benefits and problems (Cohn, 1997).

Post-Freud, a consensus developed within psychoanalysis concerning the problematic nature of same-sex sexualities. Spencer (1995) has noted that 'in the 1940s and 1950s American psychoanalysts such as Bieber, Bergler and Socarides mobilised an almost McCarthyite zeal in labelling homosexuals as sick, inadequate personalities, and 
“grievance collectors”’ (p.321). Same-sex sexualities became more intensely problematised than other forms of 'non-reproductive’ sexual behaviour such as masturbation and other forms of sexual 'perversion'. Same-sex desire and practices were regarded as perversion and pathology, as indicators of incomplete development and psychological immaturity and as requiring change (Freud, 1977). The processes by which homosexuality came to be seen in this way have been explored at length by others (see Miller, 1995; Spencer, 1995; Sullivan, 1995). It has been suggested that these views are not surprising as they have their roots in selective, essentialist, bioreproductive epistemologies (Spinelli, 1996, 1997) and in the overt biological focus that preoccupied psychoanalysis in the 1960s and 1970s (Weeks, 1989, 1999). These hypotheses are supported by the analytic literature that frequently invokes concepts related to 'natural law' (Sullivan, 1995). Examples of this include declarations such as 'The male-female design...is anatomically determined' (Socarides, 1995a, p.28) and Rayner’s (1986) view that gay male sexuality ‘involves the playing of “male” and "female" roles in sexual partnerships with the anus standing in for the vagina as often as not' (p.179). The conflation of sexuality and gender (seen in the quotation from Rayner) is also evident in the Jungian literature, where Jung suggests that male homosexuality is an identification with the feminine archetype (Hopcke, 1989; Kulkarni, 1998). Within this perspective, lesbianism can also be regarded as a woman’s identification with the masculine archetype (Hopcke, 1989).

A natural outcome of seeing same-sex sexualities in terms of perversion and pathology is that the therapist is led to construct the extinguishing of these sexualities (and their replacement with heterosexuality) as a legitimate therapeutic aim (see MacIntosh, 1992, 1997). Indeed, heterosexuality has been identified as a key indicator 
of successful psychoanalytic psychotherapy (Klein, 1932), with some analysts seeing homosexuality as a counterindication to therapy (Malan, 1976) or to psychoanalytic training (Ellis, 1994). Weeks (1989) has noted that these views spread much further than the confines of psychoanalytic institutes as, in the 1950s and 1960s, other professional disciplines adopted similar outlooks and practices that focused on adjustment to heterosexist norms. For example, in social work, it was thought that therapeutic case work could assist homosexual women in 'making astonishing moves towards femininity' and men in 'overcoming homosexuality, achieving new status in work, and doubling their earning capacities’ (Weeks, 1989, p.236).

It is important to note that, whilst the pathologisation of homosexuality and the call to eliminate same-sex sexualities and replace them with heterosexuality is particularly evident in the early psychoanalytic literature, it is not just an historical phenomenon; many theorists still advocate this perspective today both in the USA (Nicolosi, 1991; Socarides, 1995a, 1995b) and in the UK (Rayner, 1986; Limentani, 1994; Zachary, 1997). These views are actively propagated by such organisations as the National Association for Research and Therapy of Homosexuality in the USA (Sullivan, 1998). Thus, the clinician working with lesbian and gay clients within a psychoanalytic/psychodynamic framework may be influenced by a theoretical history and professional literature that advises the therapist to view the sexuality of their clients as something that is problematic and in need of change.

This is not the whole picture however. Psychoanalytic authors have noted that achieving a therapeutic 'cure' of homosexuality is problematic. Freud wrote that: 
In actual numbers, the successes achieved by psychoanalytic treatment of...homosexuality...is not very striking...In general, to undertake to convert a fully developed homosexual into a heterosexual isn’t much more promising than to do the reverse. (cited in Sullivan, 1998, p.99)

More contemporary authors have concurred with this view (Isay, 1989; Lewes, 1995). In addition, as we noted earlier, there is now a growing psychoanalytic literature that has taken issue with traditional psychoanalytic views of same-sex sexualities. Freud's (1935) 'Letter to an American Mother' is often used to support the acceptability of a non-pathologising stance towards male homosexuality (Friedman, 1988; Isay, 1989). In this letter, Freud wrote:

Homosexuality is assuredly no advantage, but it is nothing to be ashamed of, no vice, no degradation, it cannot be classified as an illness... Many highly respectable individuals of ancient and modern times have been homosexuals, several of the greatest men among them (Plato, Michelangelo, Leonardo da Vinci, etc). It is a great injustice to persecute homosexuality as a crime, and cruelty too'. (p.786)

The extent to which 'progressive' writers depart from the standard psychoanalytic viewpoint varies. Some retain the notion of 'abnormality' and admit that same-sex sexualities could be seen as a disturbance, whilst arguing that lesbians and gay men should not be judged 'by the same standards as heterosexuals who benefited from normal gender identity development' (Schwartz, 1995, p.118). In addition, other analysts, such as Meltzer (1998), have deemed homosexuality to be 'pointless' (in its 
non-reproductive nature) but reject any need to change it. Although such views construct same-sex sexualities in terms of developmental disturbance and genderbased abnormality, these authors represent their views as objective and factual rather than as homo-negative. On the other hand, the psychoanalytic writers cited at the start of this article depart much more radically from the traditional psychoanalytic view of same-sex sexualities, whilst (usually) striving to retain their standing as psychoanalysts. For example, Lewes (1995) has suggested that 'the view of homosexuals as necessarily damaged and unhappy people possessed no coherent theoretical or clinical justification’ (p.95). His writing also includes statements to the effect that 'way too many analysts have violated basic norms of decency in their treatment of homosexuals’ (Lewes, 1995, p.9), a point echoed by Isay (1989) and O’Connor and Ryan (1993). Although the debate on same-sex sexualities continues within psychoanalysis, with many issues remaining unresolved (see Phillips et al., 2001), it has been contended that psychoanalysis has at least actively engaged with its ambivalence towards same-sex sexualities (Flaks, 1993; Roughton, 1993; Gordon, 1995; Sullivan, 1998).

\section{Other Literatures}

The professional psychiatric, psychological and psychotherapeutic bodies have also contributed to more recent debates about the nature of same-sex sexualities and any shift in viewpoint within psychoanalytic communities must be seen within this broader context. In line with thinking in the 1940s and 1950s, the first edition of the American Psychiatric Association’s (APA) Diagnostic and Statistical Manual (DSM) of Mental Disorders included homosexuality in its list of sociopathic disorders (American Psychiatric Association, 1952). In the next edition, issued in 1968, 
homosexuality was moved to the category of 'other non psychotic mental disorders' and, in 1973, the APA voted to remove 'homosexuality' as an official diagnostic category from the DSM . In 1987, the last vestige of the APA's institutional pathologisation of homosexuality was removed when 'ego dystonic homosexuality' (describing instances where a person has failed to accept their homosexuality and consequently experiences persistent distress and wishes to be heterosexual) did not appear in DSM-III-R. Likewise, in 1975 the American Psychological Association adopted the official policy that homosexuality per se does not imply any kind of mental health impairment and urged mental health professionals to take the lead in removing the stigma of mental illness that had long been associated with same-sex sexualities. Both this body and later the British Psychological Society have published position papers, research reports and guidelines on psychological therapy with lesbian and gay clients that stress the need to undo the pathologisation of lesbian and gay sexualities, advocate the acceptance of same-sex sexualities in therapeutic contexts and denounce attempts to change the sexuality of lesbian and gay clients (American Psychological Association Committee on Lesbian and Gay Concerns, 1991; Garnets et al., 1991; Milton, 1998; American Psychological Association Division 44/Committee on Lesbian, Gay, and Bisexual Concerns Joint Task Force on Guidelines for Psychotherapy with Lesbian, Gay, and Bisexual Clients, 2000).

These changing official perspectives meant that psychotherapeutic approaches to lesbian and gay clients varied depending on which formulation was accepted and therapists tended to be unclear about how to treat their lesbian and gay clients. One suspects that some therapists may not have amended their conceptualisations and practices in light of DSM and other changes - on the grounds that these changes were 
seen as resulting from political and social pressure which distorted 'objective truth' but instead adhered to the official view of same-sex sexualities that accorded with their personal outlook and/or the outlook espoused by their training or therapeutic professional body. This seems to be especially so in psychoanalytic circles, to judge from accounts of lesbian and gay clients' experiences of psychoanalytic therapy and from psychoanalytic therapists' expressed views of same-sex sexualities (Phillips et al., 2001).

The literature on lesbians’ and gay men's experiences of therapeutic services provides a useful vantage point from which to consider this issue in relation to a range of psychotherapeutic schools rather than solely psychoanalysis (Garnets et al., 1991; Proctor, 1994; Golding, 1997; Annesley and Coyle, 1998; McFarlane, 1998; Milton and Coyle, 1998, 1999; Milton et al., 2002). With its focus on client accounts, it avoids falling into the gap (and sometimes the chasm) that can exist between theory and practice, although it is appreciated that the accounts which constitute this literature cannot always be taken at face value. In summary, this research paints a picture of both positive and negative therapeutic practice. The former is characterised by accurate awareness and knowledge of the contexts and meanings of lesbians' and gay men's lives and by high levels of emotional competence resulting in respectful and caring therapeutic relationships. In contrast, the latter is characterised by a lack of such awareness, knowledge and competence.

\section{Lesbian and Gay Affirmative Therapy}

Over the course of the past two decades, a literature has developed on 'lesbian and 
gay affirmative psychotherapy’ (hereafter referred to as 'affirmative therapy'), which attempts to identify and elaborate those viewpoints and practices that foster positive and effective therapeutic work with lesbian and gay clients. The general consensus in this literature appears to be that affirmative therapy is grounded in certain concepts, skills and qualities of being (many of which characterise good practice with any client group), underpinned by a belief in the acceptability of same-sex sexualities and a thorough understanding of their nature, dynamics and challenges (Malyon, 1982; Davies and Neal, 1996, 2000; Ellis, 1997; Shelley, 1998; Harrison, 2000; Milton et al., 2002).

One quality that is regarded as central to affirmative practice (and sometimes so fundamental that it is not explicitly stated) is the therapist's ability to view same-sex sexualities as being as normal, natural and healthy as any other sexual orientations (Hitchings, 1994, 1997; Young, 1995; Davies, 1996; Haldeman, 2000; Morrow, 2000). This has also been espoused by some psychoanalytic insiders (Kwawer, 1980; Isay, 1989; Ratigan, 1995; Izzard, 2000). Another key quality is that affirmative therapists should be of the opinion that sexuality per se is not the cause of the psychological difficulties presented by lesbian and gay clients (Kingdon, 1979; Malyon, 1982; Garnets et al., 1991; Milton and Coyle, 1998; Haslam, 2000) - a position that may be facilitated or rendered difficult by the therapist's theoretical stance. However, it is deemed acceptable to believe that negative social evaluations of and responses to same-sex sexualities may cause or exacerbate clients’ distress. Hence, a contextual focus is thought to be important as it assists therapists in assessing whether problems are primarily related to personal dynamics or to antilesbian and gay prejudice (Gonsiorek, 1985; Falco, 1991; Young, 1995; Dworkin, 
2000). Such a contextual focus could be seen as a response to calls for therapists to think more widely than in terms of 'self-contained' individuals (Strawbridge, 1996).

The affirmative therapist's ability to empathise with the experience of their lesbian and gay clients is said to be important in increasing their understanding of their clients (Stein, 1988; Moon, 1994; Davies, 2000). Therefore it is suggested that the therapist should be knowledgeable about lesbian and gay sexualities (McWhirter and Mattison, 1985; Rochlin, 1985; Cabaj, 1988; Buhrke, 1989; Isay, 1989; Murphy, 1991; Ratigan, 1995; Liddle, 1996; Browning et al., 1997; Shannon and Woods, 1997; Milton and Coyle, 1998; Gray, 2000) and particularly about the stresses associated with being lesbian or gay in discriminatory contexts (Malyon, 1982; Falco, 1991; Greene, 1994; Hancock, 1995; Young, 1995; McCarn and Fessinger, 1996; Annesley and Coyle, 1998; Davies, 2000; Hancock, 2000; Izzard, 2000). A final common theme in the literature concerns the need for the therapist to be open about and comfortable with their own sexual identity in order to avoid personal issues related to sexuality becoming entangled with their clients’ issues (McWhirter and Mattison, 1985; Falco, 1991; Garnets et al., 1991; Hayes and Gelso, 1993; Hitchings, 1994; Brown, 1996; Liddle, 1996; Davies, 2000; Dworkin, 2000; Izzard, 2000; Perlman, 2000). This parallels the importance accorded to the therapist's level of comfort with their ethnic identity when engaged in cross-cultural work (American Psychological Association Education and Training Committee, 1981; Atkinson et al., 1998; Palmer and Laungani, 1999).

It is clear from this overview that a therapist's stance towards same-sex sexualities including what might be termed their countertransferential response - has been 
deemed to be of prime importance in determining whether a therapist can work in a constructive way with lesbian and gay clients. Indeed, this dimension is foregrounded from the outset in the 'Guidelines for Psychotherapy with Lesbian, Gay, and Bisexual Clients’ produced by the American Psychological Association (American Psychological Association Division 44/Committee on Lesbian, Gay, and Bisexual Concerns Joint Task Force on Guidelines for Psychotherapy with Lesbian, Gay, and Bisexual Clients, 2000). However, the extent to which an accepting and affirmative stance can be incorporated into different schools of therapeutic theory and practice will vary according to the core assumptions of these schools, with some requiring more significant amendment than others in order to accommodate an affirmative stance. This is a potentially problematic issue because the greater the change that is required, the greater the likelihood of it being resisted, not only because of antilesbian and gay prejudice but also because fundamental change may be seen as eroding the very basis of a particular therapeutic tradition. This is an important consideration because the 'official' stance of a therapist's theoretical orientation and training will undoubtedly help to shape their outlook on same-sex sexualities and their response to lesbian and gay clients, even though research has suggested that personal factors also play an important role in shaping practitioners’ attitudes (Annesley and Coyle, 1995). With this in mind, we now turn to the findings of an empirical study conducted by the authors - which are relevant to the issue of countertransference when working with lesbian and gay clients.

\section{Empirical Findings on Countertransference Issues with Lesbian and Gay Clients}

Findings are drawn from a qualitative study that investigated understandings of lesbian and gay affirmative therapy held by 14 therapists (accredited by the United 
Kingdom Council for Psychotherapy, the British Association for Counselling and Psychotherapy or the British Psychological Society’s Divisions of Clinical or Counselling Psychology) who described themselves as practising in an affirmative way, and 18 clients who said they had received affirmative therapy for at least three months and whose sexuality had been attended to in a sensitive and productive manner in therapy. The participants included male $(n=14)$ and female $(n=4)$ clients, heterosexual female therapists $(n=3)$, lesbian therapists $(n=2)$ and gay male therapists $(n=9)$; no heterosexual male therapists responded to calls for participants. In terms of ethnicity, all but one of the participants identified as 'white'. The mean age of the therapists was 43 years (range 28-64) and of the clients, 37 years (range 24-58). The majority of participants had been educated to postgraduate level (13 therapists - 92.9 per cent; 9 clients - 50 per cent). Therapist participants described their practice in terms of a range of theoretical orientations, most commonly psychoanalytic/psychodynamic, integrative, humanistic and systemic. Clients reported entering therapy to address a range of problems, including addiction, anxiety, depression, bereavement, sexuality-related issues and family and relationship problems. The forms of therapy which they most frequently said they had experienced were humanistic, psychoanalytic/psychodynamic and cognitive-behavioural. Participants were interviewed individually about their views and experiences. Interview tapes were transcribed and data were subjected to analysis using grounded theory procedures (Glaser and Strauss, 1967; Pidgeon, 1996; Pidgeon and Henwood, 1996). In the quotations that follow, empty square brackets indicate where material has been omitted and three dots indicate a short pause; material that has been added for clarification appears within square brackets; words in upper case lettering convey emphasis. Pseudonyms are used to indicate the sources of the quotations and 
participants are identified either as 'a client' or 'a therapist'.

Participants from a range of theoretical orientations frequently attended to the issue of countertransference (even though this was not an explicit part of the interview schedule), sometimes invoking psychoanalytic discourse directly and at other times talking about the feelings, thoughts and values that therapists experience or hold in relation to lesbian and gay clients and how these affect the meanings and practices available to them. All participants expressed the view that countertransference (however conceived) underlies many of the processes in psychotherapy. Indeed, they felt that therapists' experiences of, thoughts about and emotional responses towards lesbian and gay clients are central to a full engagement with these clients. The perceived potential effects of personal and countertransference issues on the therapeutic process are now considered; the most salient aspects of participants' viewpoints are represented diagrammatically in Figure 1 (the lines between the boxes indicate where one issue follows from and elaborates another).

\section{[ insert Figure 1 about here ]}

As illustrated at the top of Figure 1, participants indicated that an awareness of the therapist's own stance or views was important. Many participants demonstrated an awareness of this in two domains - firstly in relation to themselves and their own sexuality and secondly in relation to same-sex sexualities in general. Participants reported that same-sex sexualities raise specific issues for therapeutic work and they explored this in emotional terms, describing some of the feelings they experienced in relation to same-sex sexualities. The impact of the therapist's sexual 
identity was thought to be relevant in this respect for both heterosexual and lesbian and gay therapists, as indicated in the third level of boxes on the left side of Figure 1. For example, reflecting on her heterosexuality, Natalie (a therapist) talked of a sense of inadequacy and said 'I’ve always felt slightly inadequate for being a straight woman [ ] like I don't have the credentials or the cred or the [ ] in-depth knowledge of the [lesbian and gay] scene'. Speaking as a gay man, Ben (a therapist), talked of 'fear' saying that, as his clients’ issues may sometimes be similar to his own, 'it’s terrifying to be dealing with gay men's issues straight and full on'. Thus, the experiences of a heterosexual woman and a gay man (other examples could have been chosen) both highlight the perceived central role of the therapist's sexuality and how working with lesbians and gay men can have an emotional impact on the therapist.

The therapist participants noted that a therapist's countertransferential feelings often help to identify areas where the therapist would benefit from undertaking 'extra work' in order to respond effectively to their lesbian and gay clients. As indicated in Figure 1, the participants identified particular areas on which therapists (both heterosexual therapists and lesbian and gay therapists) might have to work. They highlighted the difficulties that heterosexual therapists may experience when trying to reflect on their developmental needs in order to engage fully with the emotional aspects of lesbian and gay clients' experiences. Maggie (a therapist) felt that it would be difficult for heterosexual therapists to overcome countertransferential anxieties about same-sex sexualities. Whilst not denying that it would be possible, she felt that it would require a great deal of effort: 'I think it’s quite difficult if you're a heterosexual therapist frankly...I think you probably need to be racked with angst a great deal of the time'. Participants also suggested that when clients need to discuss explicit sexual material, 
this may be difficult for heterosexual therapists if they lack familiarity with and understanding of the nature and meaning of lesbians' and gay men's sexual behaviour. It was suggested that gender might have an influence on the emotionality of the response, particularly for heterosexual therapists. Brad (a therapist) said that he harboured fewer 'concerns about lesbians [clients] working with heterosexual women [therapists]. Many heterosexual women I know seem to truly understand that a woman could love another woman. I think heterosexual men and women have more difficulty with cock sucking and fucking among men’. Other participants also suggested that heterosexual therapists may need to work particularly hard to be able to empathise with lesbian or gay clients' experiences. It was felt that this extra effort might require well-informed supervision or personal therapy (see also Milton 1998; Pett 2000).

As mentioned above, the participants drew attention to issues for lesbian and gay therapists as well as for heterosexual therapists and believed that some countertransference issues might affect lesbian and gay therapists more acutely than heterosexual therapists. For example, by being more informed about specific social mores that characterise lesbian and gay communities, it was felt that there might be a 'danger of a gay therapist and a gay client colluding in a folie à deux, where both accept certain aspects of the gay lifestyle as OK, when the fact is they're not, e.g. [ ] promiscuous [ ] sex and the gay therapist accepts this as perfectly fine, whereas a heterosexual therapist might say "What's going on here?”' (Brad, a therapist); similarly, Tony (a therapist) believed there was a danger of the therapist 'colluding with sub-cultural issues [ ] that might be unhealthy'. Although these quotations could be seen as pathologising some manifestations of same-sex sexuality, another way of 
viewing them is to see the speakers as suggesting that any behaviour may be healthy or unhealthy depending on the context and the meaning it has for the individual. This was explicitly voiced by Tom (a psychoanalytic psychotherapist) in his consideration of gay sadomasochism: 'Of course it’s OK, if [the client is] enjoying that [but if] he's trying to tell you that he's not sure whether he does or not [ ] or maybe he does enjoy it but maybe it still leaves him feeling bad or whatever [ ] - it's how to challenge the behaviour without the identity'.

As indicated in the fifth and sixth levels of Figure 1, participants suggested that lesbian or gay therapists might need to pay particular attention to the differences that exist between themselves and other lesbians and gay men. Thus, they may develop an increased understanding of the way in which they interpret and express their same-sex attractions (and specifically that their experience is not generalisable). It was felt that this would help them to avoid over-identification with (or pathologisation of) clients and to attend to the individuality and specific meaning of the client. This risk was viewed as a function of the individual therapist's unconscious processes and, as such, as a function of the countertransference.

Thus far, our elaboration of Figure 1 has focused on some potential difficulties that participants felt might be created by the therapist's feelings and how these could adversely affect the therapeutic process. This was not a unanimous view, however, as many participants felt that 'you could [ ] have explored yourself in your own therapy whilst becoming a therapist - issues around your feelings around...sexually towards men and women and differences and explored your own sexuality’ (Kyle, a client). Whether attained through therapy or through other experiences, participants suggested 
that therapists can work effectively with lesbians and gay men when they adopt a positive, accepting stance towards same-sex sexualities on an emotional, intellectual and behavioural level (indicated by the second and third levels on the right side of Figure 1). Chris (a client) felt that 'absolutely a respect for homosexuality' is necessary for effective practice. Anna (a therapist) felt that the therapist should 'value the client [ ] to make explicit that their way of life is valid for them'. Exemplifying such a stance, Maggie (a therapist) said that 'I genuinely believe that [ ] being a lesbian or gay man is an entirely positive choice'.

Participants saw negative countertransference as based on the therapist's conscious or unconscious fears. It was suggested that fear often underpins a defensive and pathologising stance towards same-sex sexualities. Greg (a client) described his initial experience of therapy as difficult because '[the therapist] was just too frightened'. This was said to be problematic as 'they [the therapist's fears] will reinforce their [the client's] own fears, their own concerns or their own negative view of themselves' (Dean, a therapist). Nadia (a client) felt that when the therapist is insecure and 'fearful, then they start being defensive and start attacking and pathologising [ ] and the person who internally goes “UGHHH” when you say "I'm a lesbian” or when you [ ] talk about sex and sexuality - [ ] there's this freezing up kind of fear reaction'. Negative countertransference was therefore felt to be damaging to the client and the therapeutic process and was seen to be the responsibility of the therapist (see the far right of Figure 1).

If this situation occurs, participants felt that psychotherapy would not be possible and would be likely to end prematurely. This is of course not helpful and, when working 
in the public sector with its limited options for therapeutic engagement, not acceptable. Brad (a therapist) was not convinced that therapists (particularly heterosexual therapists) would easily be able to overcome problematic reactions to same-sex sexualities. He described having had conversations with 'pretty sophisticated psychotherapists who are a bit disturbed by [same-sex sexualities]' Reflecting on the existence of limits to acceptance, he felt that 'if one of [their] children were gay [they] wouldn't have any problems with it but what if [they] had three children and all of them were gay? That's the challenge'. In any form of therapy, it is important that the therapist is able to withstand what the client finds overwhelming. If the therapist holds negative views of a client's sexuality, they might not be able to engage with the client's own anxieties in this regard. Greg (a client) felt that the therapist needs to be able 'to recognise [sexual] desire and not be terrified by it and scared out of their pants and run away or to be stuck in some kind of [ ] professional mode of being that protects them from it'.

Both clients and therapists elaborated the parameters of a positive stance towards same-sex sexualities by seeing it as more than a value that should be held by the therapist; instead, they saw it as denoting a position where the therapist is able to identify actively with same-sex desires. It was therefore seen as advantageous for the therapist 'to know the possibility of themselves being attracted to somebody of the same sex even if they've never acted on it' (Nadia, a client) (see the second box from the bottom in Figure 1). This might prove extremely difficult if a therapist holds negative views of same-sex sexualities. However, an awareness of potential overlap between the actual experience of the client and at least the imagined experience of the therapist (as well as a recognition of difference, as we noted earlier) was seen as 
important, as it may help to increase the degree of engagement between the therapist and the client (see the box at the bottom of Figure 1). This was regarded as necessary in order for the client to experience the therapeutic encounter as open, trusting, warm and genuine. Where the therapist's values and emotional capabilities allow them to engage positively with same-sex sexualities, Jennifer (a therapist) felt that 'there's more likelihood that people are on the same wavelength [ ] so they [clients] won't need to explain so much - more of an instant empathy perhaps and the trust that the person [therapist] isn't going to judge your sexuality'. She felt that this might even allow clients to 'talk negatively about your [i.e., their] sexuality and about your sexual partner because, you know, the person [therapist] wouldn't be making assumptions [like] “Oh right, it’s true what I thought about gay people all the time”, The ability to talk negatively about one's experience can be an aspect of developing realistic ideas about a sense of self. Thus, where the therapist's critical views of same-sex sexualities make this too risky, the client may be denied the chance of engaging in important exploratory conversations and thinking.

\section{Conclusion}

As indicated in the recent psychoanalytic literature and by the research participants, the countertransferential issues involved in psychotherapy with lesbians and gay men urgently require further attention. This must include attention to theory, practice and training at a general level and at the level of individual psychotherapists and their own assumptions (whilst being mindful of the reservations expressed in the study about the possibility of therapists overcoming negative views). It is important that issues such as these are also debated more widely in the professional arena. All the time that countertransferential difficulties (whether in relation to sexuality, gender, 
race or any other area of therapist-client difference) are avoided and hidden within a discourse of 'objectivity', psychotherapy trainees are denied the space to think critically and creatively about their clinical work and clients face potentially difficult or harmful psychotherapeutic experiences (McHenry and Johnson, 1993). In addition, established therapists are denied the pleasure and challenge of ongoing development in their professional thinking and practice.

This research suggests that all therapists regardless of gender, age or sexual identity might usefully consider how their own world views affect their stance towards samesex sexualities, whether it be at the level of formulation, choice of intervention or engagement with clients. The growing literature on therapeutic practice with lesbian and gay clients and the development of professionally-approved guidelines for sensitive and appropriate practice with these client groups (American Psychological Association Division 44/Committee on Lesbian, Gay, and Bisexual Concerns Joint Task Force on Guidelines for Psychotherapy with Lesbian, Gay, and Bisexual Clients, 2000) suggest that, at the beginning of a new century, many psychotherapists are eager to attend to issues of sexuality and countertransference more directly and creatively than has previously been the case. For the sake of our lesbian and gay clients, this should be strongly encouraged.

\section{References}

American Psychiatric Association (1952) Diagnostic and Statistical Manual of 
Mental Disorders, Washington, D.C.: American Psychiatric Association. American Psychological Association Committee on Lesbian and Gay Concerns (1991) American Psychological Association Policy Statements on Lesbian and Gay Issues, Washington, D.C.: American Psychological Association. American Psychological Association Division 44/Committee on Lesbian, Gay, and Bisexual Concerns Joint Task Force on Guidelines for Psychotherapy with Lesbian, Gay, and Bisexual Clients (2000) 'Guidelines for psychotherapy with lesbian, gay, and bisexual clients’, American Psychologist, 55: 1440-51.

American Psychological Association Education and Training Committee (1981)

Cross Cultural Counseling Competence, Washington, D.C.: American Psychological Association.

Annesley, P. and Coyle, A. (1995) ‘Clinical psychologists’ attitudes to lesbians’, Journal of Community \& Applied Social Psychology, 5: 327-31.

Annesley, P. and Coyle, A. (1998) ‘Dykes and psychs: lesbian women’s experiences of clinical psychology services', Changes: An International Journal of Psychology and Psychotherapy, 16: 247-58.

Atkinson, D.R., Morten, G. and Sue, D.W. (1998) Counseling American Minorities: A Cross-Cultural Perspective ( $5^{\text {th }}$ edn.), Boston, MA: McGraw-Hill.

Brown, L. (1996) ‘Ethical concerns with sexual minority patients’, in R. Cabaj and T. Stein (eds) Textbook of Homosexuality and Mental Health, Washington, D.C.: American Psychiatric Press.

Browning, C., Reynolds, A.L. and Dworkin, S.H. (1997) ‘Affirmative psychotherapy for lesbian women', in D.R. Atkinson and G. Hackett (eds) Counseling Diverse Populations ( $2^{\text {nd }}$ edn.), Boston, MA: McGraw-Hill.

Buhrke, R. (1989) 'Training issues for counseling psychologists in working with 
lesbian women and gay men’, Counseling Psychologist, 19: 216-34.

Cabaj, R. (1988) 'Homosexuality and neurosis: considerations for psychotherapy’, Journal of Homosexuality, 15(1-2): 13-23.

Cohn, H. (1997) Existential Thought and Therapeutic Practice: An Introduction to Existential Psychotherapy, London: Sage.

Cornett, C. (1995) Reclaiming the Authentic Self: Dynamic Psychotherapy with Gay Men, Northvale, NJ: Jason Aronson.

Davies, D. (1996) 'Towards a model of gay affirmative therapy’, in D. Davies and C. Neal (eds) Pink Therapy: A Guide for Counsellors and Therapists Working with Lesbian, Gay and Bisexual Clients, Buckingham: Open University Press.

Davies, D. (2000) 'Person-centred therapy’, in D. Davies and C. Neal (eds) Therapeutic Perspectives on Working With Lesbian, Gay and Bisexual Clients, Buckingham: Open University Press.

Davies, D. and C. Neal (eds) (1996) Pink Therapy: A Guide for Counsellors and Therapists Working with Lesbian, Gay and Bisexual Clients, Buckingham: Open University Press.

Davies, D. and Neal, C. (eds) (2000) Therapeutic Perspectives on Working with Lesbian, Gay and Bisexual Clients, Buckingham: Open University Press.

Domenici, T. and Lesser R.C. (eds) (1995) Disorienting Sexuality: Psychoanalytic Reappraisals of Sexual Identities, London: Routledge.

Dreschner, J. (1999) Psychoanalytic Therapy and the Gay Man, Hillsdale, NJ: The Analytic Press.

du Plock, S. (1997) 'Sexual misconceptions: a critique of gay affirmative therapy and some thoughts on an existential-phenomenological theory of sexual orientation', Journal of the Society for Existential Analysis, 8(2): 56-71. 
Dworkin, S.H. (2000) 'Individual therapy with lesbian, gay, and bisexual clients', in R.M. Perez, K.A. DeBord and K.J. Bieschke (eds) Handbook of Counseling and Psychotherapy with Lesbian, Gay, and Bisexual Clients, Washington, D.C.: American Psychological Association.

Ellis, M.L. (1994) ‘Lesbians, gay men and psychoanalytic training’, Free Associations, 4: 501-18.

Ellis, M.L. (1997) 'Who speaks? Who listens? Different voices and different sexualities’, British Journal of Psychotherapy, 13: 369-83.

Falco, K.L. (1991) Psychotherapy with Lesbian Clients: Theory into Practice, New York: Brunner/Mazel.

Flaks, D. (1993) ‘Homophobia and psychoanalysis: a reply to Roughton’, Psychoanalytic Psychotherapy, 10: 599-600.

Freud, S. (1935) 'Letter to an American mother’, American Journal of Psychiatry (1951), 107: 786.

Freud, S. (1977) On Sexuality, London: Penguin.

Friedman, R. (1988) Male Homosexuality: A Contemporary Psychoanalytic Perspective, New Haven, CT: Yale University Press.

Garnets, L., Hancock, K. A., Cochran, S. D., Goodchilds, J. and Peplau, L. A. (1991) 'Issues in psychotherapy with lesbians and gay men: a survey of psychologists’, American Psychologist, 46: 964-72.

Glaser, B.G. and Strauss, A.L. (1967) The Discovery of Grounded Theory: Strategies for Qualitative Research, Chicago, IL: Aldine.

Golding, J. (1997) Without Prejudice: MIND Lesbian, Gay and Bisexual Mental Health Awareness Research, London: MIND Publications.

Gonsiorek, J.C. (ed.) (1985) A Guide to Psychotherapy with Gay and Lesbian Clients, 
New York: Harrington Park Press.

Gordon, P. (1995) 'Private practice, public life: is a psychoanalytic politics possible?’, Free Associations, 5: 275-88.

Gray, J. (2000) ‘Cognitive-behavioural therapy’, in D. Davies and C. Neal (eds) Therapeutic Perspectives on Working with Lesbian, Gay and Bisexual Clients, Buckingham: Open University Press.

Greene, B. (1994) 'Lesbian and gay sexual orientations: implications for clinical training, practice, and research’, in B. Greene and G.M. Herek (eds) Lesbian and Gay Psychology: Theory, Research, and Clinical Applications, Thousand Oaks, CA: Sage.

Haldeman, D.C. (2000) ‘Therapeutic responses to sexual orientation: psychology’s evolution', in B. Greene and G.L. Croom (eds) Education, Research, and Practice in Lesbian, Gay, Bisexual, and Transgendered Psychology: A Resource Manual, Thousand Oaks, CA: Sage.

Hancock, K.A. (1995) 'Psychotherapy with lesbians and gay men’, in A.R. D’Augelli and C.J. Patterson (eds) Lesbian, Gay, and Bisexual Identities Over the Lifespan: Psychological Perspectives, New York: Oxford University Press.

Hancock, K.A. (2000) 'Lesbian, gay, and bisexual lives: basic issues in psychotherapy training and practice’, in B. Greene and G.L. Croom (eds) Education, Research, and Practice in Lesbian, Gay, Bisexual, and Transgendered Psychology: A Resource Manual, Thousand Oaks, CA: Sage. Harrison, N. (2000) 'Gay affirmative therapy: a critical analysis of the literature', British Journal of Guidance \& Counselling, 28: 37-53.

Haslam, D. (2000) 'Analytical psychology’, in D. Davies and C. Neal (eds) Therapeutic Perspectives on Working with Lesbian, Gay and Bisexual Clients, 
Buckingham: Open University Press.

Hayes, J.A. and Gelso, C.J. (1993) 'Male counselors’ discomfort with gay and HIV infected clients’, Journal of Counseling Psychology, 40: 86-93.

Hitchings, P. (1994) 'Psychotherapy and sexual orientation', in P. Clarkson and M. Pokorny (eds) Handbook of Psychotherapy, London: Routledge.

Hitchings, P. (1997) ‘Counselling and sexual orientation’, in S. Palmer \& G. McMahon (eds) Handbook of Counselling, London: Routledge.

Hopcke, R. (1989) Jung, Jungians and Homosexuality, Boston, MA: Shambhala.

Isay, R. (1989) Being Homosexual: Gay Men and Their Development, London: Penguin.

Izzard, S. (1999) 'Oedipus - baby or bathwater? A review of psychoanalytic theories of homosexual development', British Journal of Psychotherapy, 16: 43-55.

Izzard, S. (2000) 'Psychoanalytic psychotherapy', in D. Davies and C. Neal (eds) Therapeutic Perspectives on Working with Lesbian, Gay and Bisexual Clients, Buckingham: Open University Press.

Kingdon, M.A. (1979) 'Lesbians’, Counseling Psychologist, 8: 44-5.

Klein, M. (1932) The Psycho-Analysis of Children, New York: Delacorte.

Kulkarni, C. (1998) ‘Radicalising Jungian theory’, in C. Shelley (ed.) Contemporary Perspectives on Psychotherapy and Homosexualities, London: Free Association Books.

Kwawer, J. (1980) 'Transference and countertransference in homosexuality: changing psychoanalytic views', American Journal of Psychotherapy, 34: 72-80.

Laird, J. and Green, R. (eds) (1996) Lesbians and Gays in Couples and Families: A Handbook for Therapists, San Francisco, CA: Jossey-Bass.

Lewes, K. (1995) Psychoanalysis and Male Homosexuality, Northvale, NJ: Aronson. 
Liddle, B. (1996) 'Therapist sexual orientation, gender and counseling practices as they relate to ratings of helpfulness by gay and lesbian clients', Journal of Counseling Psychology, 43: 394-401.

Limentani, A. (1994) 'On the treatment of homosexuality’, Psychoanalytic Psychotherapy, 8: 49-62.

MacIntosh, H. (1992) ‘Attitudes and experiences of psychoanalysts in analyzing homosexual patients', Journal of the American Psychiatric Association, 42: 1183-207.

MacIntosh, H. (1997) 'Factors associated with outcome of psychoanalysis of homosexual patients', British Journal of Psychotherapy, 13: 358-68.

Malan, D. (1976) Individual Psychotherapy and the Science of Psychodynamics, Oxford: Butterworth Heinemann.

Malley, M. and McCann, D. (2002) 'Family therapy with lesbian and gay clients', in A. Coyle and C. Kitzinger (eds) Lesbian \& Gay Psychology: New Perspectives, Oxford: BPS Blackwell.

Malley, M. and Tasker, F. (1999) 'Lesbians, gay men and family therapy: a contradiction in terms?', Journal of Family Therapy, 21: 3-29.

Malyon, A.K. (1982) 'Psychotherapeutic implications of internalized homophobia in gay men', in J. Gonsiorek (ed.) Homosexuality and Psychotherapy: A Practitioner's Handbook of Affirmative Models, New York: Haworth Press.

McCarn, S.R. and Fessinger, R.E. (1996) 'Revisioning of sexual minority identity formation: a new model of lesbian identity and its implications for counseling and research', Counseling Psychologist, 24: 508-34.

McFarlane, L. (1998) Diagnosis: Homophobic. The Experiences of Lesbians, Gay Men and Bisexuals in Mental Health Services, London: PACE. 
McHenry, S.S. and Johnson, J.W. (1993) 'Homophobia in the therapist and gay or lesbian client: conscious and unconscious collusions in self-hate', Psychotherapy, 30: 141-51.

McWhirter, D. and Mattison, A. (1985) 'Psychotherapy for gay male couples’, in J.C. Gonsiorek (ed.) A Guide to Psychotherapy with Gay and Lesbian Clients, New York: Harrington Park Press.

Meltzer, D. (1998) 'The decline of the male (after Spengler)', keynote paper Psychosexual Currents at the Turn of the Century, Association of Group and Individual Psychotherapy, London; $17^{\text {th }}$ October.

Miller, N. (1995) Out of the Past: Gay and Lesbian History from 1869 to the Present, New York: Vintage Books.

Milton, M. (1998) Issues in Psychotherapy with Lesbians and Gay Men: A Survey of British Psychologists, Leicester: British Psychological Society Division of Counselling Psychology.

Milton, M. (2000) 'Is existential psychotherapy a lesbian and gay affirmative psychotherapy?’, Journal of the Society for Existential Analysis, 11(1): 86102.

Milton, M. and Coyle, A. (1998) ‘Psychotherapy with lesbian and gay clients’, The Psychologist, 11: 73-6.

Milton, M. and Coyle, A. (1999) 'Lesbian and gay affirmative psychotherapy: issues in theory and practice', Sexual and Marital Therapy, 14: 43-59.

Milton, M., Coyle, A. and Legg, C. (2002) 'Lesbian and gay affirmative psychotherapy: defining the domain', in A. Coyle and C. Kitzinger (eds) Lesbian \& Gay Psychology: New Perspectives, Oxford: BPS Blackwell.

Moon, L. (1994) ‘Counselling with lesbians and gay men’, Changes: An International 
Journal of Psychology and Psychotherapy, 12: 277-83.

Morrow, S.L. (2000) 'First do no harm: therapist issues in psychotherapy with lesbian, gay, and bisexual clients’, in R.M. Perez, K.A. DeBord and K.J. Bieschke (eds) Handbook of Counseling and Psychotherapy with Lesbian, Gay, and Bisexual Clients, Washington, D.C.: American Psychological Association.

Murphy, B. (1991) 'Educating mental health professionals about gay and lesbian issues’, Journal of Homosexuality, 22(3-4): 229-46.

Nicolosi, J. (1991) Reparative Psychotherapy of Male Homosexuality, Northvale, NJ: Jason Aronson.

O’Connor, N. and Ryan, J. (1993) Wild Desires and Mistaken Identities: Lesbianism and Psychoanalysis, London: Virago.

Palmer, S. and Laungani, P. (1999) Counselling in a Multicultural Society, London: Sage.

Perlman, G. (2000) ‘Transactional analysis’, in D. Davies and C. Neal (eds)

Therapeutic Perspectives on Working with Lesbian, Gay and Bisexual Clients, Buckingham: Open University Press.

Pett, J. (2000) ‘Gay, lesbian and bisexual therapy and its supervision’, in D. Davies and C. Neal (eds) Therapeutic Perspectives on Working with Lesbian, Gay and Bisexual Clients, Buckingham: Open University Press.

Phillips, P., Bartlett, A. and King, M. (2001) 'Psychotherapists’ approaches to gay and lesbian patients/clients: a qualitative study’, British Journal of Medical Psychology, 74: 73-84.

Pidgeon, N.F. (1996) 'Grounded theory: theoretical background', in J.T.E. Richardson (ed.) Handbook of Qualitative Research Methods for Psychology 
and the Social Sciences, Leicester: BPS Books.

Pidgeon, N.F. and Henwood, K.L. (1996) ‘Grounded theory: practical implementation', in J.T.E. Richardson (ed.) Handbook of Qualitative Research Methods for Psychology and the Social Sciences, Leicester: BPS Books.

Proctor G. (1994) ‘Lesbian clients’ experience of clinical psychology: a listener’s guide', Changes: An International Journal of Psychology and Psychotherapy, 12: $290-8$.

Ratigan, B. (1995) 'Inner world, outer world: exploring the tensions of race, sexual orientation and class and the inner world', Psychodynamic Counselling, 1: 173-86.

Ratigan, B. (1998) 'Psychoanalysis and male homosexuality: queer bedfellows’, in C. Shelley (ed.) Contemporary Perspectives on Psychotherapy and Homosexualities, London: Free Association Books.

Rayner, E. (1986) Human Development: An Introduction to the Psychodynamics of Growth, Maturity and Ageing, London: Routledge.

Rochlin, M. (1985) 'Sexual orientation of the therapist and therapeutic effectiveness with gay clients’, in J.C. Gonsiorek (ed.) A Guide to Psychotherapy with Gay and Lesbian Clients, New York: Harrington Park Press.

Roughton, R.E. (1993) 'Response to Flaks’ “Homophobia and the psychologist’s role in psychoanalytic training institutes”', Psychoanalytic Psychotherapy, 10: 597.

Ryan, J. (1998) 'Lesbianism and the therapist’s subjectivity: a psychoanalytic view’, in C. Shelley (ed.) Contemporary Perspectives on Psychotherapy and Homosexualities, London: Free Association Books.

Schwartz, D. (1995) 'Current psychoanalytic discourses on sexuality: tripping over 
the body’, in T. Domenici and R.C. Lesser (eds) Disorienting Sexuality: Psychoanalytic Reappraisals of Sexual Identities, London: Routledge.

Shannon, J.W. and Woods, W.J. (1997) ‘Affirmative psychotherapy for gay men’, in D.R. Atkinson and G. Hackett (eds) Counseling Diverse Populations (2 ${ }^{\text {nd }}$ edn.), Boston, MA: McGraw-Hill.

Shelley, C. (ed.) (1998) Contemporary Perspectives on Psychotherapy and Homosexualities, London: Free Association Books.

Silvester, K. (2000) 'Psychosynthesis’, in D. Davies and C. Neal (eds) Therapeutic Perspectives on Working with Lesbian, Gay and Bisexual Clients, Buckingham: Open University Press.

Smith, D.L. (1991) Hidden Conversations: An Introduction to Communicative Psychoanalysis, London: Routledge.

Socarides, C.W. (1995a) Homosexuality: A Freedom Too Far, Phoenix, AZ: Adam Margrave Books.

Socarides, C.W. (1995b) 'On the treatment of homosexuality’, invited talk in the School of Psychotherapy and Counselling, Regent's College, London; $28^{\text {th }}$ April.

Spencer, C. (1995) Homosexuality: A History, London: Fourth Estate.

Spinelli, E. (1996) 'Some hurried notes expressing outline ideas that someone might someday utilise as signposts towards a sketch of an existentialphenomenological theory of sexuality', Journal of the Society for Existential Analysis, 8(1): 2-20.

Spinelli, E. (1997) 'Human sexuality and existential-phenomenological inquiry’, Counselling Psychology Review, 12: 170-8.

Strawbridge, S. (1996) 'Myth of the self-contained individual in counselling 
psychology’, a paper presented at the Third Annual Conference of the British Psychological Society’s Division of Counselling Psychology, York; $26^{\text {th }}-28^{\text {th }}$ April.

Stein, T. (1988) 'Theoretical considerations in psychotherapy with gay men and lesbians', Journal of Homosexuality, 15(1-2): 75-95.

Sullivan, A. (1995) Virtually Normal: An Argument about Homosexuality, London: Picador.

Sullivan, A. (1998) Love Undetectable: Reflections on Friendship, Sex and Survival, London: Chatto and Windus.

Ussher, J. (1990) ‘Cognitive-behavioural couples’ therapy with gay men referred for counselling in an AIDS setting: a pilot study', AIDS Care, 1: 43-51.

Weeks, J. (1989) Sex, Politics and Society: The Regulation of Sexuality Since 1800, London: Longman.

Weeks, J. (1999) Making Sexual History, Cambridge: Polity Press.

Young, V. (1995) The Equality Complex - Lesbians in Therapy: A Guide to AntiOppressive Practice, London: Cassell.

Zachary, A. (1997) 'Psychotherapy of sexual deviation and perversion', Current Opinion in Psychiatry, 10: 251-5. 


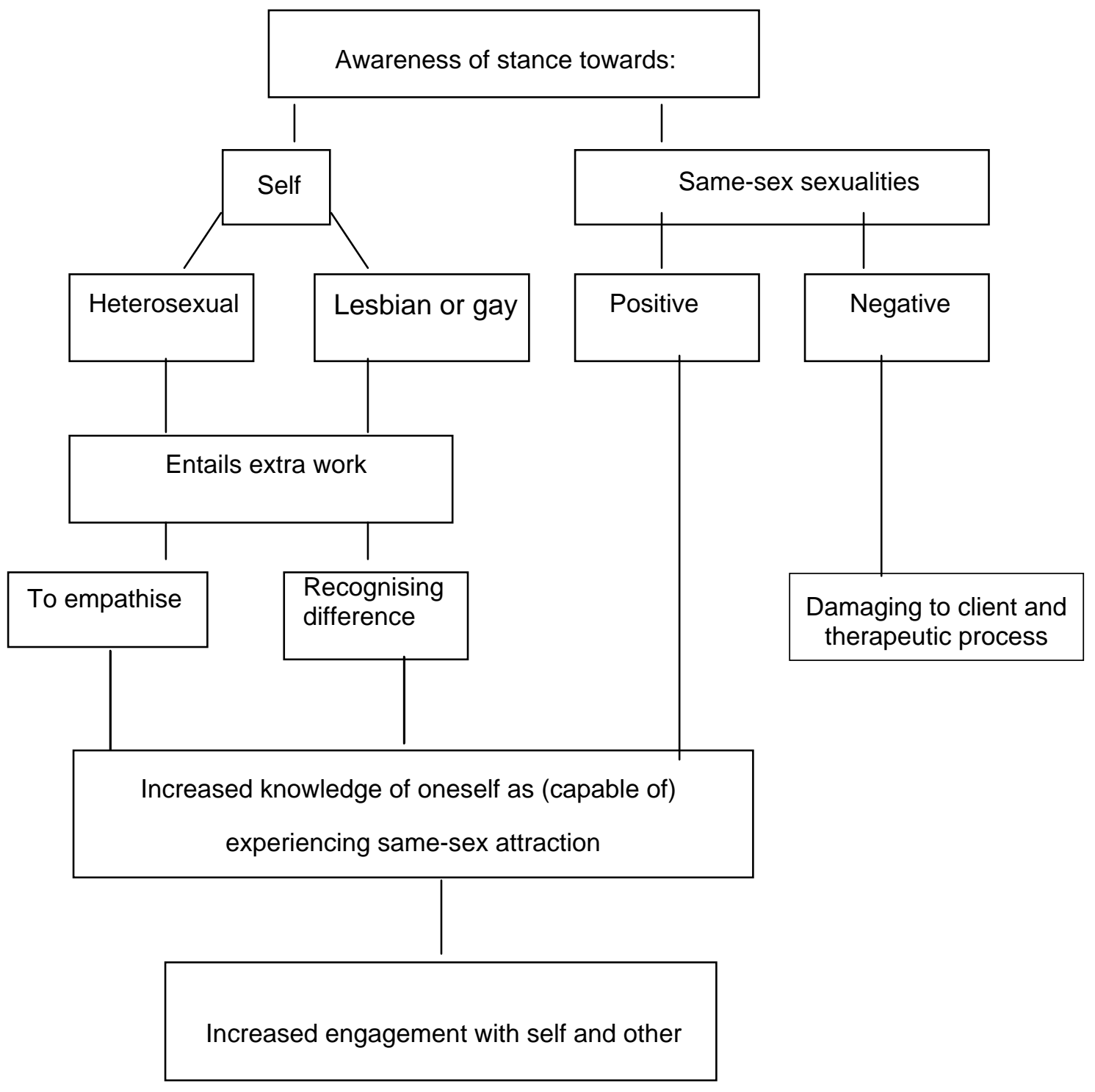

Figure 1: An empirically-derived model of countertransference processes related to psychotherapeutic work with lesbian and gay clients. 